\title{
3. O PODER JUDICIÁRIO: FUNÇÕES, ORGANIZAÇÃO E AUTONOMIA
}

\subsection{Identificação e funções do Poder Judiciário}

Já se fez referência nos capítulos anteriores à origem do Poder Judiciário, sua inserção no Estado como um dos poderes que o integram e lhe dão forma, bem como o papel que ocupa sob a ótica da Administração Pública.

Com isso, já se tem uma noção a respeito das funções que exerce, o que será visto com maior detalhamento neste item, embora não se pretenda aprofundar a discussão, que é extensa e complexa, uma vez que o presente trabalho pretende focar-se nas questões pertinentes aos aspectos financeiros da autonomia atribuída a este Poder, por força de expressa disposição constitucional (art. 99). Nos capítulos anteriores, já se pôde vislumbrar a dificuldade em se encontrar consenso sobre a exata conformação e funções do Poder Judiciário.

O Poder Judiciário pode ser visto sob vários ângulos, conforme o aspecto que se queira considerar. Tem duas faces, nas palavras de Maria Teresa Sadek: "uma de poder de Estado e, outra, de instituição prestadora de serviços". ${ }^{53}$

Neste ponto, ajustam-se as classificações já mencionadas por Eros Grau - às quais já se fez referência no item 1.2 -, que, no aspecto subjetivo, considera os poderes "centros ativos de funções, ou seja, os órgãos incumbidos de sua execução", cabendo ao Poder Judiciário, essencialmente, a função jurisdicional, de aplicação das normas jurídicas (aspecto material). ${ }^{54}$

O Poder Judiciário, no âmbito de Poder do Estado, já teve sua noção suficientemente aclarada nos capítulos anteriores, sendo o caso de incursionar no campo

\footnotetext{
${ }^{53}$ Judiciário: mudanças e reformas, p. 79.

${ }^{54} \mathrm{O}$ direito posto..., p. 236-7.
} 
das funções por ele exercidas e dos serviços por ele prestados. Dar-se-á ênfase, evidentemente, às funções típicas do Judiciário. ${ }^{55}$

Assim, pode-se identificar o Poder Judiciário como um conjunto de órgãos aos quais se atribui a função jurisdicional.

Para Agustín Gordillo, a função jurisdicional é "la decisión con fuerza de verdad legal de controversias entre partes, hecha por un órgano imparcial e independiente". ${ }^{56}$ Cabe ao Poder Judiciário "aplicar contenciosamente a lei a casos particulares", nas palavras de Pedro Lessa ${ }^{57}$, ou "compor conflitos de interesse em cada caso concreto", como expressa José Afonso da Silva. ${ }^{58}$

Não é tarefa simples tornar precisas essas atribuições que se conferem ao Poder Judiciário, pois compõem uma gama de atividades relacionadas à administração da justiça que não se distinguem facilmente daquelas exercidas pelos outros poderes.

Manoel Gonçalves Ferreira Filho aponta o problema:

De fato, em sua substância essa função é executar ou aplicar a lei a casos particulares. Ora, executar a lei é objeto de outra função, a executiva, ou administrativa. Destarte, limitando-se a pôr em prática, em casos concretos, decisões anteriores de caráter geral, o Judiciário exerceria uma função por sua natureza igual à desempenhada pela administração. [...]

$\mathrm{Na}$ verdade, é difícil compreender como se pode sustentar que, em sua substância, seja a "função judiciária" ou "jurisdicional" distinta da função "executiva" ou "administrativa". O único ponto por que uma pode ser distinguida da outra é o modo de execução da lei a que obedece ao Judiciário.

De fato, este aplica a lei contenciosamente, isto é, com a possibilidade rigorosamente garantida de debate entre as partes interessadas no litígio. Abre-se perante ele sempre a possibilidade do contraditório, permitindo-se a todos os que serão afetados pela decisão fazerem ouvir suas razões, seus argumentos.

O modo, porém, não muda a natureza da função. Ademais, o Direito

\footnotetext{
${ }^{55}$ Não é de interesse, para este item, a referência a funções atípicas, tais como as administrativas (promover licitações, organizar secretarias) ou legislativas (elaborar regimentos, regular o funcionamento de serviços).

${ }^{56}$ Tratado de Derecho Administrativo, t. I, p. IX-13.

${ }^{57}$ Do Poder Judiciário, p. 1. 58.

${ }^{58}$ Curso..., p. 522.
} 
comparado mostra bem que órgãos de caráter estritamente administrativos podem ser jungidos a abrir contenciosos para aplicar a lei a casos particulares. É o caso dos tribunais, ou como se usa dizer, dos contenciosos administrativos. ${ }^{59}$

Não é o caso de dar maior extensão ao assunto, pois, em linhas gerais, os Estados especificam as funções atribuídas ao Poder Judiciário, e, uma vez estabelecida e reconhecida a organização do Estado em três poderes distintos, cabe analisar a forma pela qual este Poder se organiza para cumprir sua missão.

Ver-se-á que esta dificuldade na identificação precisa das tarefas que compõem a função jurisdicional reflete-se na forma de organização do Poder Judiciário, encontrando-se, nos diversos Estados, diferenças nas funções exercidas por este Poder.

\subsection{Organização do Poder Judiciário}

Tendo em vista o princípio do duplo grau de jurisdição, normalmente o Poder Judiciário tem, ao menos, duas instâncias: o primeiro grau, para o qual são apresentadas a maior parte das causas; e o segundo grau, com a competência, em regra, de apreciar os recursos interpostos contra as decisões de primeiro grau, estabelecendo assim o que se pode chamar de estrutura vertical do Poder Judiciário.

O primeiro grau de jurisdição, na generalidade dos casos, é composto por juízes que decidem isoladamente as questões, enquanto os órgãos de grau superior são colegiados, com as decisões sendo tomadas por grupos de juízes.

É comum haver um órgão de cúpula, que pode funcionar algumas vezes como um terceiro grau de jurisdição, dependendo da forma de organização adotada.

Pode-se identificar também uma diferente estrutura horizontal do Poder Judiciário. Vários países estabelecem uma divisão funcional do Poder Judiciário, criando justiças especializadas conforme a matéria discutida. No Brasil, por exemplo, isso ocorre em matéria eleitoral, trabalhista e militar. Há países com tribunais especializados em matéria fisscal, como o Canadá, e previdenciária, como a França.

${ }^{59}$ Curso..., p. 240-1. 
A organização do Estado, no que se refere à repartição territorial do Poder, exerce grande influência na estrutura adotada pelo Poder Judiciário. Admitindo a dicotomia "Estados unitários" e "Estados Federais" $" 60$, em cada uma dessas formas de organização do Estado o Poder Judiciário apresenta conformações diferentes. Nos Estados Federais, essa organização tende a ser bastante complexa, envolvendo divisões no Poder Judiciário em função de matéria discutida, pessoas envolvidas e outras, estabelecendo-se justiças especializadas em razão da matéria e em diferentes esferas de governo.

O Brasil e os Estados Unidos, por exemplo, têm a Justiça Federal e a Justiça Estadual. A primeira é organizada em âmbito nacional, composta por juízes servidores do governo federal, e a segunda é organizada no âmbito dos Estados, composta por juízes servidores dos respectivos governos estaduais. Em ambos os casos, a atribuição de competência dá-se em razão da matéria objeto de discussão. No Brasil, a competência da Justiça Federal é especificada nos arts. 108 e 109 da CF, cabendo-lhe julgar, precipuamente, as causas em que a união for interessada. A Justiça Estadual tem competência residual, ficando responsável pelas causas não atribuídas expressamente à Justiça Federal, nem às demais Justiças Especiais. Os Estados unidos adotam regra semelhante, atribuindo à Justiça Federal as causas que envolvem o governo federal, a Constituição Federal, a interpretação de leis federais e as controvérsias envolvendo Estados da Federação ou entre governo federal e governos estrangeiros; a Justiça Estadual cuida de questões familiares, imobiliárias, contratuais, de heranças, de responsabilidade civil e da maior parte das questões relacionadas às causas criminais. ${ }^{61}$

Há também diferenças significativas decorrentes da abrangência da função jurisdicional.

No Brasil, o chamado "contencioso administrativo" dá-se no âmbito do Poder Executivo, no qual se podem encontrar, na esfera federal, os Conselhos de Contribuintes, órgãos colegiados que funcionam no Ministério da Fazenda, com

\footnotetext{
${ }^{60}$ A discussão sobre a validade e a pertinência dessa classificação é extensa e complexa. Já fizemos referência a ela quando escrevemos "Federalismo fiscal e fundos de participação", especialmente item 1.3, não sendo conveniente estender-se no tema, por não ter, neste momento do trabalho, relevância suficiente para justificar o desvio da linha de raciocínio.

${ }^{61}$ USA. Administrative Office of the U.S. Courts. The Federal Court system in the United States, p. 16.
} 
competência para apreciar questões de natureza fiscal. Na esfera estadual, também na área fiscal, há, no Estado de São Paulo, o Tribunal de Impostos e Taxas, que funciona na Secretaria da Fazenda. Além desses órgãos, há inúmeros outros, nas esferas federal, estadual e municipal, com competência para apreciar e decidir sobre reclamações dos cidadãos contra atos da Administração Pública, decididas na esfera do Poder Executivo. $\mathrm{Na}$ França, a organização judiciária prevê uma divisão em duas grandes ordens, a judiciária e a administrativa. Os Tribunais Administrativos (Tribunal Administratif) julgam os litígios entre os cidadãos e os poderes públicos, e suas decisões são submetidas à reapreciação em segunda instância pela Corte Administrativa de Apelação (Cour Administrative d'Appel), submetidas ao controle do Conselho de Estado (Conseil d'Etat).

Na Itália, o Ministério Público (Pubblico Ministero) integra a Magistratura (Constituição italiana, art. 107), diferentemente do que ocorre no Brasil, em que tem natureza de uma instituição independente ( $\mathrm{CF}$, art. 127). Os membros do Ministério Público francês (Ministère Public, ou Parquet) também são magistrados (Constituição francesa, art. 65).

Essas são algumas das principais diferenças na conformação do Poder Judiciário que evidenciam a multiplicidade de possibilidades em sua organização.

A organização do Poder Judiciário no Brasil será vista com mais detalhes a seguir.

\subsection{O Poder Judiciário no Brasil}

De início, far-se-á um breve histórico da evolução do Poder Judiciário no Brasil, destacando-se eventualmente aspectos relacionados à sua autonomia e às finanças, para posteriormente estabelecer-se um quadro com a estrutura atualmente vigente no Poder Judiciário brasileiro.

No período colonial, o Poder Judiciário e o Poder Executivo eram exercidos pela mesma pessoa, o Governador-Geral, que tinha no Ouvidor-Geral um encarregado pelos negócios da Justiça, o qual exercia jurisdição nas áreas cível e criminal, julgando e 
aplicando as penas. Nesse período, foram criados dois tribunais de instância superior, o Tribunal de Relação da Bahia, em 1609, e o Tribunal de Relação do Rio de Janeiro, em 1751.62

A primeira Constituição do Brasil, da época do Império, promulgada em 25 de março de 1824 por Dom Pedro I, previu a existência de quatro poderes: o Poder Legislativo, o Poder Moderador, o Poder Executivo e o Poder Judicial (art. 10). Além disso, essa Constituição previa um Supremo Tribunal de Justiça, na capital do Império, e Tribunais de Relação na capital e nas províncias (art. 163).

$\mathrm{O}$ art. 151 assegurava expressamente a independência do Poder Judicial; no entanto, essa independência é questionável, pois o art. 154 dava ao Imperador o poder de suspender os Juízes ${ }^{63}$, e o art. 153, embora estabelecendo que "os Juízes de Direito serão perpétuos", autorizava, nos termos da lei, a mudança de lugar. Como Otaviano Nogueira bem observa, "não se pode dizer que o Judiciário constituísse, na prática, um poder independente, na forma como hoje se concebe a harmonia e independência que presidem os diferentes poderes do Estado democrático". Ressalta, logo a seguir, que: "A rigor, portanto, o texto constitucional negava, na prática, duas garantias tradicionais da Magistratura - a vitaliciedade e a inamovibilidade e não assegurava a irredutibilidade de vencimentos -, ainda que duas disposições diferentes lhes garantissem, teoricamente, tanto uma como outra". 64

Não havia autonomia administrativa, financeira ou orçamentária. ${ }^{65}$

Na Constituição de 1891, o Brasil deixou de ser um Estado unitário para tornarse uma República Federativa, institucionalizando-se a Justiça Federal e o Supremo Tribunal Federal, que haviam sido criados por Campos Sales no Governo Provisório.

$\mathrm{O}$ art. 15 considerava “órgãos da soberania nacional o Poder Legislativo, o Executivo e o Judiciário, harmônicos e independentes entre si", extinguindo-se, por óbvio, o Poder Moderador.

\footnotetext{
${ }^{62}$ ARAÚJO. O Estado..., p. 52-3.

${ }^{63}$ Também previsto no art. 101, VII, que enumera os poderes do Imperador no exercício do Poder Moderador.

${ }^{64}$ Constituição de 1824, p. 36.

${ }^{65}$ DARÓS, Dificuldades da Justiça Federal brasileira, p. 56.
} 
A independência do Poder Judiciário tornou-se mais efetiva com a abolição da suspensão dos Juízes, que podia ser feita pelo Imperador, assegurando-se expressamente, no art. 57, a vitaliciedade e a irredutibilidade de vencimentos.

A autonomia administrativa começou a se fazer presente, como se pode depreender do art. 58: “Os Tribunais Federais elegerão de seu seio os seus presidentes e organizarão as respectivas secretarias".

Com o movimento revolucionário de 1930, houve a instalação de um Governo Provisório, e o Decreto $\mathrm{n}^{\mathrm{o}}$ 19.398, de 1930, investindo-se de força institucional, aboliu a Constituição vigente e convocou a Assembleia Constituinte, que deu origem à Carta de 1934. Esse Governo Provisório unificou os Poderes Executivo e Legislativo, que passaram a ser por ele exercidos discricionariamente (art. $1^{\circ}$ do Decreto). $\mathrm{O}$ art. $3^{\circ}$ do Decreto manteve o Poder Judiciário, mas o art. $5^{\circ}$ suspendeu garantias constitucionais e excluiu da apreciação do Poder Judiciário os atos do Governo Provisório. Foi criado um Tribunal Especial para assuntos políticos, que deixaram de ser apreciados pelo Judiciário. ${ }^{66}$

Na Constituição de 1934, houve a tentativa de unificação da Justiça, o que, no entanto, não foi aprovado, mantendo-se o sistema dual, com a Justiça Federal e a Justiça dos Estados.

Trouxe ainda a previsão da Justiça Eleitoral (arts. 82 e 83) e da Justiça Militar (arts. 84 a 87). Criou-se também a Justiça do Trabalho, no art. 122, sem que essa, no entanto, integrasse o Poder Judiciário.

No que tange às questões relacionadas à independência da Magistratura e do Poder Judiciário, mantiveram-se as garantias da vitaliciedade, inamovibilidade (com a possibilidade de movimentação motivada por interesse público, desde que com o voto de dois terços dos Juízes do Tribunal respectivo) e irredutibilidade, ressalvando-se, neste último caso, as deduções dos impostos. Foram estabelecidas restrições para o

\footnotetext{
${ }^{66}$ ARAÚJO, O Estado..., p. 180-2.
} 
exercício do cargo, com o impedimento de os juízes exercerem outras funções, bem como atividade político-partidária.

Outorgada sob a égide de um regime ditatorial, a Constituição de 1937 refletia a exacerbação dos poderes do Executivo em detrimento dos demais. ${ }^{67}$ Deixou de constar da Constituição o artigo que fazia referência à existência de três poderes, independentes e harmônicos entre si.

A redução dos poderes do Judiciário aparecia em alguns pontos, como no art. 96, que exigia maioria de votos da totalidade dos Juízes dos Tribunais para declarar a inconstitucionalidade de lei, e, mesmo assim, havendo a declaração, o Presidente da República poderia submetê-la novamente ao Parlamento, que teria a possibilidade de confirmá-la, tornando sem efeito a decisão do Tribunal. E o art. 95 vedava ao Poder Judiciário "conhecer de questão exclusivamente política".

Também houve prejuízo às garantias funcionais da Magistratura. Rosalina Araújo observa que:

\begin{abstract}
A Constituição outorgada não assegurou plenamente aos magistrados as garantias de vitaliciedade, irredutibilidade de vencimentos e inamovibilidade, não confirmando, por conseguinte, a sua autonomia e independência, ao contrário, seguindo os objetivos políticos da época, através de atos modificadores da Constituição, os magistrados foram considerados servidores públicos e ficaram também impedidos de exercer, inclusive, o magistério, mas quando em disponibilidade poderiam exercer cargos de confiança direta do Presidente da República. ${ }^{68}$
\end{abstract}

No que se refere à organização judiciária, a Constituição de 1937 não incluiu no texto a Justiça Eleitoral e extinguiu a Justiça Federal de primeira instância. ${ }^{69}$ No entanto, incluiu no texto referência à Justiça Estadual. ${ }^{70}$

\footnotetext{
67 “Art. 73. O Presidente da República, autoridade suprema do Estado, coordena a atividade dos órgãos representativos, de grau superior, dirige a política interna e externa, promove ou orienta a política legislativa de interesse nacional, e superintende a administração do País.”

${ }^{68}$ O Estado..., p. 282.

69 A década de 1930 foi marcada por várias alterações na Justiça Federal, como observa Vladimir Passos de Freitas: "Foi também na década de 30 que se extinguiu a Justiça Federal. A Carta imposta em 10.11.1937, criadora do chamado Estado Novo, pôs fim, sem qualquer referência ou justificativa, à Justiça Federal. Ela foi simplesmente excluída dos dispositivos que tratavam do Poder Judiciário, em especial o art. 90. Os seus juízes foram postos em disponibilidade, com vencimentos proporcionais. Alguns foram reaproveitados na Justiça de seus Estados" (FREITAS, Justiça federal: histórico e evolução no brasil, p.
} 
O art. 95 da Constituição de 1937 fez menção ao sistema de precatórios, prevendo que "as verbas orçamentárias e os créditos votados para os pagamentos devidos, em virtude de sentença judiciária, pela Fazenda federal, serão consignados ao Poder Judiciário, recolhendo-se as importâncias ao cofre dos depósitos públicos”.

A Constituição de 1946 refletiu a volta do regime democrático. Mantiveram-se as garantias da Magistratura da vitaliciedade, inamovibilidade e irredutibilidade de vencimentos, sem as ressalvas da Constituição de 1937 que as haviam mitigado, e com a supressão das restrições impostas à declaração de inconstitucionalidade das leis que constaram do texto de $1937 .^{71}$

$\mathrm{O}$ art. $7^{\circ}$ deixava clara a independência do Poder Judiciário:

\author{
Art. $7^{\circ}-$ O Governo Federal não intervirá nos Estados, salvo para: [...] \\ IV - garantir o livre exercício de qualquer dos Poderes estaduais; \\ V - assegurar a execução de ordem ou decisão judiciária; [...] \\ VII - assegurar a observância dos seguintes princípios: [...] \\ b) independência e harmonia dos Poderes; [...] \\ g) garantias do Poder Judiciário.
}

Quanto à organização judiciária, a referência à Justiça Eleitoral (art. 94, IV) voltou, houve previsão do Tribunal Federal de Recursos (art. 94, II), bem como dos

\footnotetext{
36).

70 “Art. 90. São órgãos do Poder Judiciário: a) o Supremo Tribunal Federal; b) os Juízes e Tribunais dos Estados, do Distrito Federal e dos Territórios; c) os Juízes e Tribunais militares”. Os arts. 103 a 110 cuidam da Justiça Estadual.

${ }^{71}$ Neste aspecto, Rosalina Araújo observa com propriedade que a "Constituição de 1946 evoluiu em relação às anteriores, tornando mais nítido o sistema de controle de constitucionalidade das leis, em parte mantendo o que já vinha disposto desde a proclamação da República com a criação do Supremo Tribunal Federal e a organização da Justiça Federal, em parte recuperando e aperfeiçoando as disposições constitucionais de 1934 e, por fim, restaurando o que havia sido prejudicado pela Carta outorgada em 1937, principalmente ao suprimir o parágrafo único do art. 96 desta Carta, que autorizava o Presidente da República a tornar sem efeito a declaração de inconstitucionalidade de lei, através de poder que detinha de submetêla novamente ao exame do Parlamento" (O Estado..., p. 287).
} 
Juízes e Tribunais do Trabalho (art. 94, v). ${ }^{72}$ Permitiu-se a criação dos Tribunais de Alçada no âmbito da Justiça Estadual (art. 124, II).

Em 9.4.1964, com a instalação do regime militar ditatorial, foi baixado o Ato Institucional 1, que, embora mantendo a Constituição de 1946 (art. $1^{\text {o }}$ ), promoveu alterações significativas na ordem jurídica, reduzindo direitos e garantias individuais, exacerbando os poderes do Presidente da República e diminuindo a independência do Poder Judiciário.

$\mathrm{O}$ art. $7^{\circ}$ do referido Ato Institucional, por exemplo, suspendeu, por seis meses, as garantias constitucionais ou legais da vitaliciedade e estabilidade, autorizando a demissão, disponibilidade e aposentadoria compulsória por ato do Comando Supremo da Revolução, após investigação sumária. $\mathrm{O} \S 4^{\circ}$ do referido artigo estabeleceu ainda que "o controle jurisdicional desses atos limitar-se-á ao exame de formalidades extrínsecas, vedada a apreciação dos fatos que o motivaram, bem como da sua conveniência ou oportunidade".

O Ato Institucional 2, de 1965, modificou artigos que tratavam do Poder Judiciário, reinserindo no texto a Justiça Federal de primeira instância (nova redação do art. 94, II, da CF).

Em 24.1.1967, foi promulgada nova Constituição, logo após alterada por vários Atos Institucionais (cabendo destacar os de números 5 e 6) e pela Emenda Constitucional 1, de 1969.

O Ato Institucional 5, de 13.12.1968, em seu art. $6^{\circ}$, suspendeu as garantias de vitaliciedade, inamovibilidade e estabilidade, autorizando o Presidente da República, por decreto, demitir, remover, aposentar ou pôr em disponibilidade os titulares das mencionadas garantias, violentando a independência funcional do Poder Judiciário. Neste, como em outros atos institucionais, ficam expressamente excluídas "de qualquer apreciação judicial todos os atos praticados de acordo com este Ato Institucional e seus Atos Complementares, bem como os respectivos efeitos" (art. 11).

\footnotetext{
72 Os Juízes e Tribunais do Trabalho passaram a integrar o Poder Judiciário, haja vista que antes a Justiça do Trabalho vinha prevista na Constituição na parte em que tratava da ordem econômica e financeira.
} 
O texto consolidado da Constituição de 1967, após as mencionadas alterações, trouxe, em seu art. $6^{\circ}$, expressa referência à independência dos poderes: "São Poderes da união, independentes e harmônicos, o Legislativo, o Executivo e o Judiciário".

Mantiveram-se as garantias da vitaliciedade, inamovibilidade e irredutibilidade de vencimentos (art. 113), bem como as competências dos Tribunais para elegerem seus presidentes e demais dirigentes (art. 115, I).

O art. 112, parágrafo único, previu que a Lei Orgânica da Magistratura Nacional deveria ser veiculada por meio de lei complementar.

Relativamente às questões financeiras, houve algumas inovações a serem destacadas.

O princípio da universalidade passou a constar do texto fazendo expressa referência aos poderes:

O orçamento anual compreenderá obrigatoriamente as despesas e receitas relativas a todos os Poderes, órgãos e fundos, tanto da administração direta quanto da indireta, excluídas apenas as entidades que não recebam subvenções ou transferências à conta do orçamento (art. 62).

$\mathrm{O}$ art. 64 previu lei complementar destinada a estabelecer limites para as despesas de pessoal da união, dos Estados e dos Municípios.

Importante dispositivo para a autonomia financeira do Poder Judiciário estava presente no art. 68:

O numerário correspondente às dotações destinadas à Câmara dos Deputados, ao Senado Federal e aos Tribunais Federais será entregue no início de cada trimestre, em quotas estabelecidas na programação financeira do Tesouro Nacional, com participação percentual nunca inferior à estabelecida pelo Poder Executivo para os seus próprios órgãos.

$\mathrm{O} \S 1^{\circ}$ do art. 117 tornava obrigatória a inclusão, no orçamento das entidades de direito público, da verba necessária ao pagamento dos precatórios judiciários. 
A Emenda Constitucional 7, de 13.4.1977, promoveu importantes alterações na estrutura do Poder Judiciário, entre as quais estava a inclusão, na estrutura deste Poder, do Conselho Nacional da Magistratura (nova redação dos arts. 112, II, e 120), a ser composto por sete Ministros do Supremo Tribunal Federal, com competência para conhecer reclamações contra membros de Tribunais, podendo avocar processos disciplinares contra juízes de primeira instância, e, em qualquer caso, determinar a disponibilidade ou a aposentadoria. O Conselho desapareceu do texto na Constituição de 1988, só reaparecendo em 2004, com a Emenda Constitucional 45, que introduziu o Conselho Nacional de Justiça, com características um pouco diferentes.

Em 5.10.1988, com a volta da democracia, foi promulgada nova Constituição, que corresponde ao texto vigente atualmente. Alterações sucessivas, por meio de emendas constitucionais ${ }^{73}$, dão forma ao Poder Judiciário brasileiro, cuja organização será explicitada a seguir.

\subsubsection{A atual organização do Poder Judiciário no Brasil}

O Poder Judiciário brasileiro tem, em sua cúpula, o Supremo Tribunal Federal e o Superior Tribunal de Justiça, bem como os Tribunais Superiores do Trabalho, Militar e Eleitoral, todos órgãos federais com sede na capital da República.

O Supremo Tribunal Federal compõe-se de onze Ministros, nomeados pelo Presidente da República depois de aprovada a escolha pelo Senado Federal (CF, art. 101). Tem por função a guarda da Constituição, com sua competência fixada basicamente no art. 102 da CF.

O Superior Tribunal de Justiça compõe-se, atualmente ${ }^{74}$, de trinta e três Ministros, nomeados pelo Presidente da República, depois de aprovada a escolha pelo Senado Federal. Um terço dos integrantes são Juízes dos Tribunais Regionais Federais, um terço são Desembargadores dos Tribunais de Justiça, e um terço são advogados e membros do Ministério Público Federal, Estadual, do Distrito Federal e Territórios. É

\footnotetext{
${ }^{73}$ Das quais cabe destaque à Emenda Constitucional 45 (Reforma do Judiciário), de 8.12.2004, publicada em 31.12.2004.

${ }^{74}$ A Constituição prevê que o STJ compõe-se de, no mínimo, trinta e três Ministros (art. 104).
} 
um "órgão de articulação e defesa do direito objetivo federal" "75, cuja competência está enumerada, essencialmente, no art. 105 da CF.

O Brasil constitui-se em uma Federação, e, em razão disso, o Poder Judiciário organiza-se nas esferas federal e estadual.

O Poder Judiciário Federal subdivide-se na chamada "Justiça Comum", representada pelos Tribunais Regionais Federais e pelos Juízes Federais, e nas "Justiças Especiais", das quais fazem parte os Tribunais e Juízes do Trabalho, os Tribunais e Juízes Eleitorais e os Tribunais e Juízes Militares.

A Justiça Federal "comum" tem sua competência fixada nos arts. 108 e 109 da $\mathrm{CF}$, cabendo-lhe fundamentalmente processar e julgar as causas em que a união for interessada. Os Juízes Federais integram a primeira instância, havendo cinco Tribunais Regionais Federais que compõem a segunda instância. O Conselho da Justiça Federal, órgão que funciona junto ao Superior Tribunal de Justiça, exerce a supervisão administrativa e orçamentária da Justiça Federal de primeiro e segundo graus, funcionando como órgão central, cujas decisões terão caráter vinculante (art. 105, parágrafo único, II, CF).

À Justiça do Trabalho compete processar e julgar as ações oriundas da relação de trabalho (art. 114, I). Tem como órgão de cúpula o Tribunal Superior do Trabalho, composto por vinte e sete Ministros, nomeados pelo Presidente da República, após aprovação do Senado Federal, observado o disposto no art. 111-A da CF. Junto a ele funciona o Conselho Superior da Justiça do Trabalho, a quem compete a supervisão administrativa, orçamentária, financeira e patrimonial da Justiça do Trabalho. Em segunda instância, funcionam os Tribunais Regionais do Trabalho, hoje em um total de vinte e quatro, e, em primeira instância, os Juízes do Trabalho.

A Justiça Eleitoral tem como órgão superior o Tribunal Superior Eleitoral, composto por sete membros, sendo três Ministros do STF, dois Ministros do STJ e dois advogados escolhidos pelo Presidente da República, após indicação do STF. Em segunda instância, funcionam os Tribunais Regionais Eleitorais, sendo um em cada

${ }^{75}$ JOSÉ AFONSO DA SILVA. Curso..., p. 525. 
Estado da Federação e no Distrito Federal. A primeira instância é composta pelos Juízes e Juntas Eleitorais.

À Justiça Militar compete processar e julgar os crimes militares. O Superior Tribunal Militar é o órgão máximo da Justiça Militar, com quinze Ministros nomeados pelo Presidente da República, após aprovação do Senado Federal, sendo três oficiaisgenerais da Marinha, quatro oficiais-generais do Exército, três oficiais-generais da Aeronáutica e cinco civis. Vários Estados da Federação (CF, art. 125, $\S 3^{\circ}$ ), como é o caso de São Paulo, têm na organização do seu Poder Judiciário o Tribunal de Justiça Militar, que funciona como órgão de segunda instância (CE, arts. 80 e 81), e os Juízes de Direito e Conselhos de Justiça, na primeira instância (CF, art. 125, $\S 3^{\circ}$ ).

A cada Estado da Federação compete organizar a Justiça Estadual, por meio da Constituição Estadual e da lei estadual de organização judiciária, observados os princípios estabelecidos na Constituição Federal. A segunda instância é representada pelo Tribunal de Justiça, uma vez que os Tribunais de Alçada foram extintos pela Emenda Constitucional 45, de 2004. Em primeira instância, a Justiça Estadual é composta pelos Tribunais do Júri, competentes para julgar os crimes dolosos contra a vida (CF, art. $5^{\circ}, \mathrm{XXXVIII,} d$ ), e pelos Juízes de Direito. Podem ainda existir Juizados Especiais para causas cíveis de menor complexidade e infrações penais de menor potencial ofensivo, que terão seus recursos submetidos a julgamento por Turmas de Recursos.

Foi introduzido na organização do Poder Judiciário, pela EC 45/04, o Conselho Nacional de Justiça, composto de quinze membros, na forma especificada no art. 103-b da CF, presidido por um Ministro do STF. Caberá ao Conselho o controle da atuação administrativa e financeira do Poder Judiciário e do cumprimento dos deveres funcionais dos Juízes, além das atribuições enumeradas no $\S 4^{\circ}$ do referido artigo, mais as que lhe forem conferidas pelo Estatuto da Magistratura.

As disposições relacionadas à autonomia, especialmente financeira, do Poder Judiciário, serão objeto de estudo nos capítulos posteriores, razão pela qual não se fará referência a elas neste momento.

\subsection{Independência e autonomia do Poder Judiciário}


$\mathrm{O}$ art. $2^{\circ}$ da $\mathrm{CF}$ brasileira dispõe: "São Poderes da união, independentes e harmônicos entre si, o Legislativo, o Executivo e o Judiciário". ${ }^{76}$

Não obstante as ponderações críticas sobre a separação dos poderes, objeto de referência no primeiro capítulo, a independência do Poder Judiciário é aspecto fundamental para a garantia do Estado Democrático de Direito.

O próprio modelo americano de concepção do Estado, com a separação de poderes submetida ao sistema de freios e contrapesos, seguido pelo Brasil, assenta-se no princípio da supremacia da Constituição, à qual se subordinam todos os Poderes, e na independência do Poder Judiciário, essencial para o funcionamento do sistema adotado. A independência do Judiciário manifesta-se principalmente pelo poder político de proceder à revisão judicial das leis e atos do governo ante a Constituição (judicial review), podendo reconhecer e declarar sua inconstitucionalidade. Também o poder de "dizer o direito", ao ter a última palavra como intérprete da ordem jurídica, tomando decisões que obrigam todos os demais poderes, faz do Judiciário um poder insuscetível de qualquer subordinação aos demais. ${ }^{77}$

A independência do Judiciário "é uma necessidade da liberdade individual [...], é condição indispensável para a liberdade e a proteção dos direitos humanos", nas palavras de Manoel Gonçalves Ferreira Filho ${ }^{78}$; “instrumento de efetiva realização da cidadania e de real garantia dos direitos", assevera José Néri da Silveira. ${ }^{79}$ "A magistratura independente é que pode garantir a eficácia das regras de comportamento social inspiradas na busca da justiça”, como nos ensina Dalmo Dallari. ${ }^{80}$

Várias Constituições fazem referência expressa à independência do Poder Judiciário, como a de Portugal $^{81}$, a da Espanha ${ }^{82}$ e a da Itália. ${ }^{83}$ Outras, embora não

\footnotetext{
${ }^{76}$ Tal dispositivo vem reproduzido em Constituições estaduais, como a do Estado de São Paulo: "Art. 5”. São Poderes do Estado, independentes e harmônicos entre si, o Legislativo, o Executivo e o Judiciário".

${ }^{77}$ Com muita propriedade manifestou-se, neste sentido, o Ministro do STF José Néri da Silveira, em aula magna proferida na Faculdade de Direito da UFRS, em 1999 (Dimensões da independência do Poder Judiciário, p. 171).

${ }^{78}$ Curso..., p. 241.

${ }^{79}$ Dimensões..., p. 177.

${ }^{80}$ O poder..., p. 48.

81 “Os tribunais são independentes e apenas estão sujeitos à lei” (art. 206).
} 
tenham artigo com redação semelhante, asseguram a independência do Poder Judiciário pelas garantias nelas previstas.

A Organização das Nações Unidas, em mais de uma oportunidade, já externou sua preocupação com a independência do Poder Judiciário, reconhecendo ser ela fundamental para assegurar os direitos e garantias individuais. Formulou os "Princípios básicos da Independência do Judiciário", e o primeiro deles não deixa dúvidas sobre sua importância e necessidade:

The independence of the judiciary shall be guaranteed by the State and enshrined in the Constitution or the law of the country. It is duty of all governmental and other institutions to respect and observe the independence of the judiciary. ${ }^{84}$

Sendo a independência do Poder Judiciário fator inerente à própria existência do Estado Democrático de Direito, torna-se necessário compreender o seu significado exato. Independência é "o estado ou condição de quem ou do que é independente, de quem ou do que tem liberdade ou autonomia". ${ }^{85}$

De Plácido e Silva explica o conceito em seu sentido jurídico:

Mostra a situação da pessoa, de um órgão ou de uma coletividade, que não está diretamente submetida à autoridade de outra pessoa, de outro órgão ou de outra coletividade. É livre na sua direção e na prática de atos, que se refiram a seus interesses ou ao desempenho de suas finalidades. [...] A independência jurídica é a que coloca a pessoa fora da autoridade de outra, para que possa agir por si mesma, não necessitando da intervenção de outrem

\footnotetext{
82 "La justicia emana del pueblo y se administra en nombre del Rey por Jueces y Magistrados integrantes del poder judicial, independientes, inamovibles, responsables y sometidos únicamente al imperio de la ley" (art. 117, 1).

83 "La magistratura costituisce un ordine autonomo e indipendente da ogni altro potere" (art. 104).

${ }^{84}$ Basic Principles on the Independence of the Judiciary. Adopted by the Seventh United Nations Congress on the Prevention of Crime and the Treatment of Offenders held at Milan from 26 August to 6 September 1985 and endorsed by General Assembly resolutions 40/32 of 29 November 1985 and 40/146 of 13 December 1985. Disponível em: www1.worldbank.org/publicsector/legal/basicPrinciples.htm. Acesso em: 19.8.2004. Dalmo Dallari também faz referência ao reconhecimento formal da independência dos juízes como requisito necessário para a democracia e a paz, realizado pela $\mathrm{ONu}$ por meio da Resolução 1.994/41, aprovada em 04.3.1994 (O poder..., p. 46).

${ }^{85}$ Dicionário Aurélio básico da língua portuguesa. Rio de Janeiro: Nova Fronteira, 1994. p. 357. Bastante semelhantes são as outras definições: "estado, condição, caráter daquele que goza de autonomia, de liberdade com relação a alguém ou alguma coisa" (Dicionário Houaiss da língua portuguesa. Rio de Janeiro: Objetiva, 2001).
} 
para que pratique os atos jurídicos de seu interesse. ${ }^{86}$

E, em seguida, faz referência ao conceito de independência com relação às instituições, evidenciando a relatividade do conceito:

Em relação às instituições, a independência jurídica se apresenta como a ausência de qualquer mando ou autoridade de outro órgão na sua administração, embora possa existir entre eles uma certa interferência de ordem administrativa, em virtude da qual tenham que atuar ou agir em harmonia, na defesa de interesses comuns. É o caso dos poderes públicos, independentes e harmônicos entre si. Neles, como se evidencia, está a exata compreensão do sentido independência, na acepção jurídica, relativa às instituições: cada uma é independente no exercício de suas funções e atribuições, de modo que uma não investe no poder jurisdicional da outra. Mas é independência relativa, pois que, entre si há uma interdependência que as orientam e harmonizam para a realização de objetivos de interesse comum. ${ }^{87}$

Para José Afonso da Silva,

[...] a independência dos poderes significa: (a) que a investidura e a permanência das pessoas num dos órgãos do governo não dependem da confiança nem da vontade dos outros; (b) que, no exercício das atribuições que lhe sejam próprias, não precisam os titulares consultar os outros nem necessitam de sua autorização; (c) que, na organização dos respectivos serviços, cada um é livre, observadas apenas as disposições constitucionais e legais. ${ }^{88}$

Os conceitos de independência e autonomia assemelham-se em muitos aspectos, verificando-se, muitas vezes, uma tautologia na definição, com um deles sendo utilizado para definir o outro.

De Plácido e Silva admite essa equivalência. Para ele, autonomia é

[...] palavra derivada do grego autonomia (direito de se reger por suas próprias leis), que se aplica para indicar precisamente a faculdade que possui determinada pessoa ou instituição, em traçar as normas de sua conduta, sem que sinta imposições restritivas de ordem estranha. Neste sentido, seja em relação às pessoas, seja em relação às instituições, o vocábulo tem significado em todo idêntico ao que expressa independência. ${ }^{89}$

\footnotetext{
${ }^{86}$ Vocabulário..., p. 454.

${ }^{87}$ Idem, p. 454.

${ }^{88}$ Curso..., p. 111.

89 Vocabulário jurídico, p. 251. Mais adiante, o autor, discorrendo sobre os vários aspectos em que se desdobra a autonomia, faz expressa referência à autonomia dos poderes, nos termos que seguem: "AUTONOMIA DOS PODERES. Expressão usada para designar a independência que se dá aos órgãos do poder público, a que se atribui uma soma de funções, geralmente chamada de poder (Poder Legislativo, Poder Judiciário e Poder Executivo), no desempenho destas mesmas funções que delimitam sua esfera de
} 
Os dicionários costumam destacar o aspecto da autogovernabilidade na definição do termo. Autonomia é a "faculdade de se governar por si mesmo", segundo Aurélio Buarque de Holanda e Silveira Bueno. ${ }^{90}$

Há de se reconhecer que, efetivamente, os conceitos de independência e autonomia confundem-se, mas, admitindo que independência é "o estado de quem tem autonomia", e sendo a autonomia a "faculdade de se governar por si mesmo", é razoável admitir-se que o conceito de independência é mais abrangente, sendo a autonomia um instrumento por meio do qual se atinge a independência, uma característica intrínseca da independência, um verdadeiro elemento que compõe o conceito de independência.

Disso se infere que o Poder Judiciário, bem como os demais, por serem independentes, nos termos do art. $2^{\circ}$ da CF, têm autonomia. Ou seja, analisando-se o disposto na Constituição pela interpretação literal, pode-se concluir que Poder Judiciário é autossuficiente para se governar.

Evidentemente, não é o que ocorre na realidade, pois o governo é exercido pelo Estado, sendo os poderes partes integrantes dele, tornando necessária uma interpretação que compatibilize os conceitos apresentados.

É necessário se compreender o conteúdo exato da autonomia de que são dotados os poderes, qual seu alcance e os precisos termos em que ela se exerce, a fim de que se possa reconhecer a existência de uma independência efetiva desses poderes, em especial do Judiciário, objeto deste trabalho.

Clèmerson Merlin Clève, ao discorrer sobre a autonomia do Poder Judiciário, expõe de maneira clara e didática a questão, ensinando que "a independência do

ação, que não pode ser invadida por outro poder. A autonomia dos poderes públicos, que também se dizem poderes constitucionais, é determinada pela própria Constituição, onde, assegurando-se sua independência relativa ao cumprimento de sua missão, se traçam as atribuições que lhes são inerentes e que constituem seu próprio poder. Todos eles, dentro de sua autonomia, exercitam atos que manifestam a própria soberania do Estado, cuja vontade soberana se objetiva por suas ações e determinações. Há independência de órgãos, mas, entre eles, existe uma harmonia de funções, que, segundo assentam os doutrinadores, decorre dessa mesma autonomia ou independência. Harmonia, aí, não significa mais que a própria colaboração ou cooperação dos três poderes autônomos na execução dos fins do Estado" (Vocabulário..., p. 252).

${ }^{90}$ Dicionário Aurélio básico da língua portuguesa, p. 74; Silveira Bueno, Grande dicionário etimológico prosódico da língua portuguesa. São Paulo: Saraiva, 1963. p. 444; é a "capacidade de se autogovernar" (Dicionário Houaiss da Língua Portuguesa. Rio de Janeiro: Objetiva, 2001). 
Judiciário é assegurada seja em virtude da (i) autonomia institucional, seja, ainda, em virtude da (ii) autonomia funcional concedida à magistratura". ${ }^{91}$

A autonomia institucional, por sua vez, desdobra-se nos princípios do autogoverno, da autoadministração, da inicialidade legislativa e da autoadministração financeira; já a autonomia funcional, nas garantias da Magistratura de vitaliciedade, inamovibilidade e irredutibilidade de vencimentos, bem como nas vedações a que estão sujeitos os Juízes (exercer outras atividades, dedicar-se a atividade político-partidária etc.).

O exercício do autogoverno evidencia-se principalmente pela competência privativa dos Tribunais de elegerem seus órgãos diretivos, conforme previsto no art. 96, I, da CF. A autoadministração está presente no poder dos Tribunais de elaborarem seus regimentos internos, organizarem suas secretarias e serviços auxiliares, concederem licenças, férias e afastamentos a juízes e servidores, bem como prover os cargos de juiz e servidores ( $\mathrm{CF}$, art. 96, I, $a, b, c$ e). O princípio da inicialidade legislativa compreende a iniciativa privativa de algumas leis, como a do Estatuto da Magistratura, a alteração no número de membros dos Tribunais inferiores, a criação e a extinção de cargos, a fixação de vencimentos de juízes e servidores, a criação ou a extinção de Tribunais inferiores e a alteração da organização e divisão judiciárias (CF, arts. 93 e 96, II). ${ }^{92}$

O "princípio da autoadministração financeira", assim denominado por Clèmerson Clève, configura a autonomia financeira, objeto central da abordagem deste trabalho, razão pela qual não se fará referência específica a ele neste momento. É, outrossim, extremamente relevante a contextualização que ora se faz do tema abordado.

\footnotetext{
${ }^{91}$ Poder Judiciário: autonomia e justiça, p. 35.

92 Poder judiciário..., p. 35-6.
} 